\title{
Application of an Antibiotic Crescent-Shaped Polymethylmethacrylate Strut in Thoracic Vertebral Tuberculosis
}

\author{
Torasik Vertebral Tüberkülozda Antibiyotik Yarım Ay Şekilli \\ Polimetilmetakrilat Destek
}

\author{
Wan JUN ${ }^{1}$, Kang YI-JUN ${ }^{2}$, Chen FEI ${ }^{2}$, Lv GUO-HUA ${ }^{2}$, Li DONG-ZHE ${ }^{2}$ \\ ${ }^{1}$ Xiangya Hospital Central South University, Department of Orthopedics, Changsha, China. \\ ${ }^{2}$ Xiangya Second Hospital Central South University, Department of Spine Surgery, Changsha, China
}

Correspondence address: Kang YI-JUN / E-mail: f2kangyijun@163.com, Wan JUN / E-mail: amiba3000@163.com

\begin{abstract}
Spinal tuberculosis accounts for up to $50 \%$ of all cases with musculoskeletal tuberculosis. In patients needing surgical treatment, the use of anterior instrumentation offers the theoretical advantage of more complete debridement and decompression, safer mobilization and reliable deformity correction. However, the placement of instrumentation in an infected area remains a matter of debate. We present a patient with thoracic vertebral tuberculosis using an antibiotic crescent-shaped PMMA strut for spinal reconstruction and fusion. The patient recovered satisfactory and no complication was observed in the follow-up. The antibiotic crescent-shaped PMMA strut can be used as a carrier for antibiotic drug and an ideal alternative for anterior spinal reconstruction. However, long-term outcome in this case requires further evaluation.

KEYWORDS: Antibiotic, Anterior reconstruction, Crescent-shaped, Polymethylmethacrylate, Spinal tuberculosis
\end{abstract}

öz

Spinal tüberküloz tüm kas iskelet tüberkülozu vakalarının \%50'sini oluşturmaktadır. Cerrahi tedavi gereken hastalarda anterior enstrümentasyon kullanımı, daha komple debridman ve dekompresyon, daha güvenli mobilizasyon ve güvenli deformite düzeltilmesi şeklinde teorik bir avantaj sunmaktadır. Ancak, enfekte bölgeye enstrümentasyon yerleştirilmesi tartışma nedenidir. Torasik vertebral tüberkülozu bulunan ve spinal rekonstrüksiyon ve füzyon için bir antibiyotik yarım ay şekilli PMMA destek yerleştirilen bir hastayı sunuyoruz. Hasta tatminkar şekilde iyileşti ve takipte bir komplikasyona rastlanmadı. Antibiyotik yarım ay şekilli PMMA destek antibiyotik ilaç için bir taşıyıcı ve anterior spinal rekonstrüksiyon için ideal bir alternatif olarak kullanılabilir. Ancak bu vakadaki uzun dönemli sonucun daha ileri değerlendirilmesi gerekir.

ANAHTAR SÖZCÜKLER: Antibiyotik, Anterior rekonstrüksiyon, Yarım ay şekilli, Polimetilmetakrilat, Spinal tüberküloz

\section{INTRODUCTION}

Spinal tuberculosis accounts for up to $50 \%$ of all cases with musculoskeletal tuberculosis. The anterior and middle column is mostly affected in these patients. Conservative therapy is the premier option for treatment of spinal tuberculosis. However, formations of paravertebral abscess, severe kyphosis, developing neurological deficit and lack of improvement or deterioration during conservative therapy are often indications for surgery $(10,27)$. In patients needing surgical treatment, the use of anterior instrumentation offers the theoretical advantage of more complete debridement and decompression, safer mobilization and reliable deformity correction $(8,11,19)$.

However, the use of spinal instrumentation has been linked with increased risk of deep infection $(7,14,22,23)$. Therefore, the placement of implants in an infected area remains a matter of debate; partly focus on questions as to whether the implants interfere with control of the infection $(7,14,25)$. Studies show that antibiotic agents mixed with PMMA beads chain can be released into surrounding soft tissues, thereby providing high antibiotic concentrations in local lesion $(2,17)$. In clinical application, antibiotic PMMA beads chain has been used in treating patients with open fractures, chronic osteomyelitis, total joint arthroplasty, and soft-tissue infections for decades $(1,13,15,16,20,24,26,28)$. But due to the specificity of reconstruction of spine, antibiotic PMMA beads chain is not appropriate to be applied because of weak support capability.

PMMA (Polymethylmethacrylate) bone cement strut has been used as an ideal alternative to treat cervical disease in some medical centre and favorable long-term outcomes have been reported $(1,4-6,9,21)$. In this article, we described an antibiotic crescent-shaped PMMA strut designed for anterior reconstruction in one case of thoracic vertebral tuberculosis. The strut was used both as a spacer for spinal 
reconstruction and as an antibiotic carrier supposed to improve the effect anti-tuberculosis accompanies with antituberculous drugs and reduce the possibility of infection after placement of instrumentation. To our knowledge, there is the first report about an antibiotic crescent-shaped PMMA strut used for spinal reconstruction and fusion following anterior reconstruction in case with thoracic vertebral tuberculosis.

\section{CASE PRESENTATION}

A 34-year-old female was admitted to the hospital for back pain, low fever, weight loss and radicular pain in his bilateral upper thighs. Neurologic examination showed reduced muscle power in both bilateral quadriceps (3/5)and anterior tibial muscles (3/5) combining with sphincter disturbance. Visual Analog scale was assessed as 8 and the Frankel scale was evaluated as D. Plain radiography and magnetic resonance imaging (MRI) studies showed destruction of the T10 and T11 vertebral bodies with anterior epidural and bilateral paraspinal abscess (Figures 1, 2). The kyphotic deformity was $30^{\circ}$ at the start of treatment (the kyphosis was measured as the angle between the upper surface of the first normal vertebra above the lesion and the lower surface of the first normal vertebra below the lesion on lateral plain radiography). The impression diagnosis was made as thoracic vertebral tuberculosis. She was initially given oral anti-tuberculous chemotherapy for 2 weeks (isoniazid (300 mg per day), rifampicin (450 mg per day), and ethambutol (500 $\mathrm{mg}$ per day)).

After general anesthesia with endotracheal intubation, the patient was placed in the right lateral decubitus position.

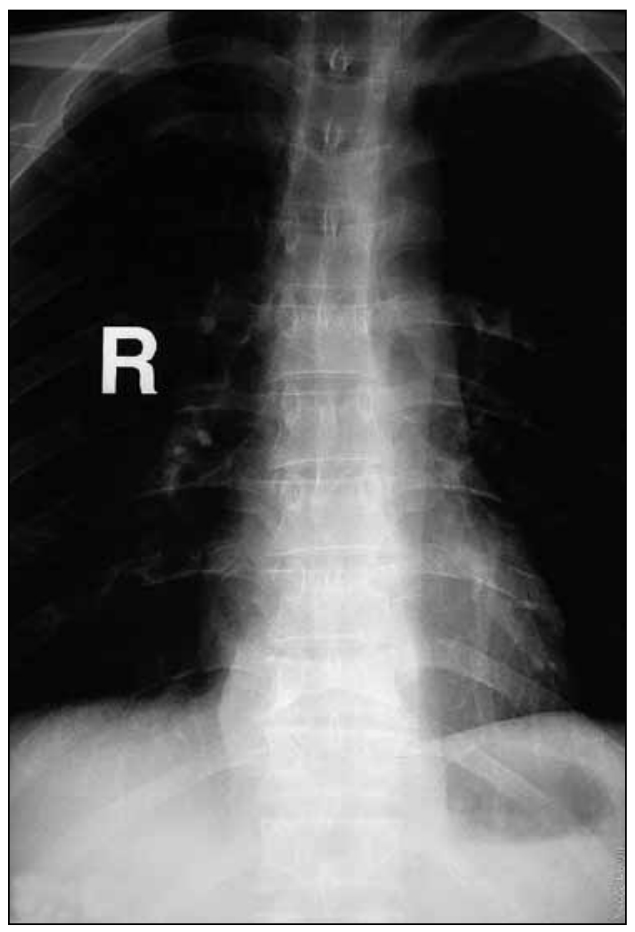

Figure 1: A 34-year-old female patient suffered severe back pain with neurological deficit of Frankel D. Preoperative plain x-ray showed destruction of the T10 and T11.
An intra-thoracic cavity-approach was used to expose the surgical region. Pus and necrotic tissue were removed as much as possible until normal bleeding bone was reached. Neural decompression was carried out with subtotal or complete corpectomy of the involved vertebrae. Before the antibiotic (levofloxacin) crescent-shaped PMMA strut (details were described in following part: Production of PMMA strut) was wedged into the defect, a Ventrofix distractor was usually used to correct the kyphotic deformity. The anterior instrumentation (Ventrofix, Synthes Inc Company, U.S.A) was placed one level above and one level below the affected vertebrae. The antibiotic (levofloxacin) crescent-shaped PMMA strut packed with autogenous rib was placed in defect area (Figure 3).

In addition to the anti-tuberculous chemotherapy (isoniazid (300 mg per day), rifampicin (450 mg per day), and ethambutol (500 mg per day) and lasted 18 months), intravenous antibiotic drug for 5 to 7 days was given to all patients after surgery. The patient was immobilized in a rigid external orthosis for 12 weeks.

Back pain improved immediately after surgery (VAS 2) and resolved gradually in two months (VAS 0). The patient was observed of increasing in urinary compliance and improvement in fecal incontinence combining with recovery muscle power both in bilateral quadriceps (5/5) and anterior tibial muscles (5/5) two-month postoperatively (Frankel scale E). The early

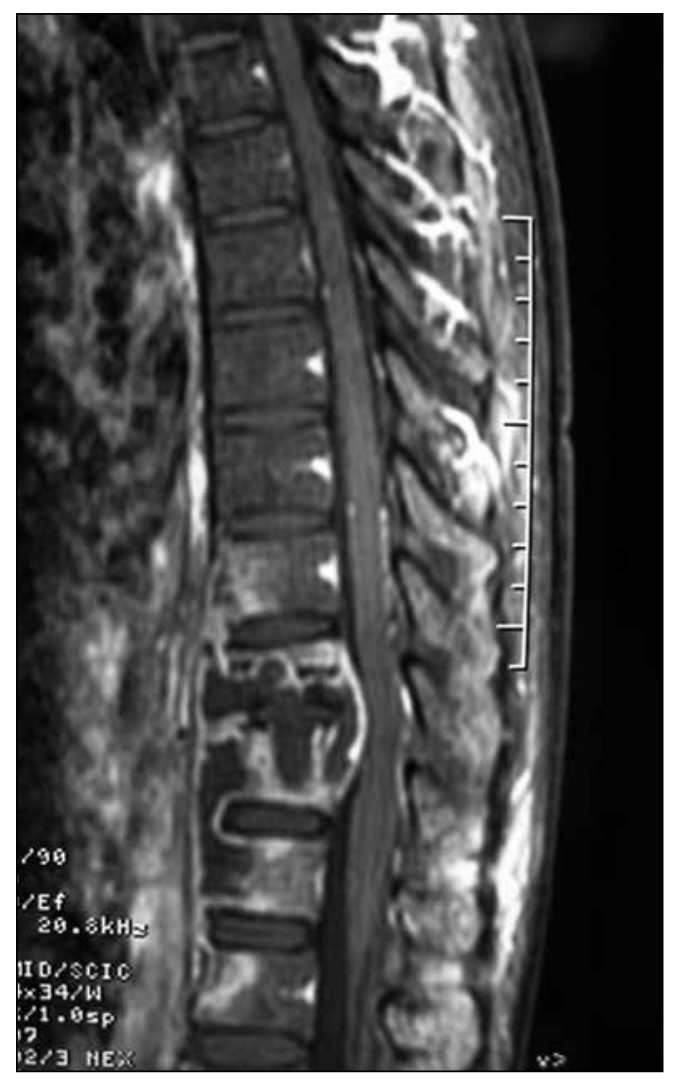

Figure 2: MRI showed destruction of the T10 and T11 vertebral bodies with anterior epidural and bilateral paraspinal abscess. 
postoperative kyphosis correction was satisfactory (kyphosis angle $2^{\circ}$ ), (Figures 4,5 ) and no significant loss of correction was identified at the final follow-up examination. No sign of tuberculosis recurrence was observed.

\section{Production of PMMA Strut}

Considering many different factors, we designed a novel antibiotic crescent-shaped PMMA strut that can easily be made in the operation room. The materials we need just include PMMA bone cement (Polymethylmethacrylate) and two syringes (one's volume is $50 \mathrm{ml}$ and the other's $20 \mathrm{ml}$ ).

Firstly the length of $50 \mathrm{ml}$ syringe was modified equally to the

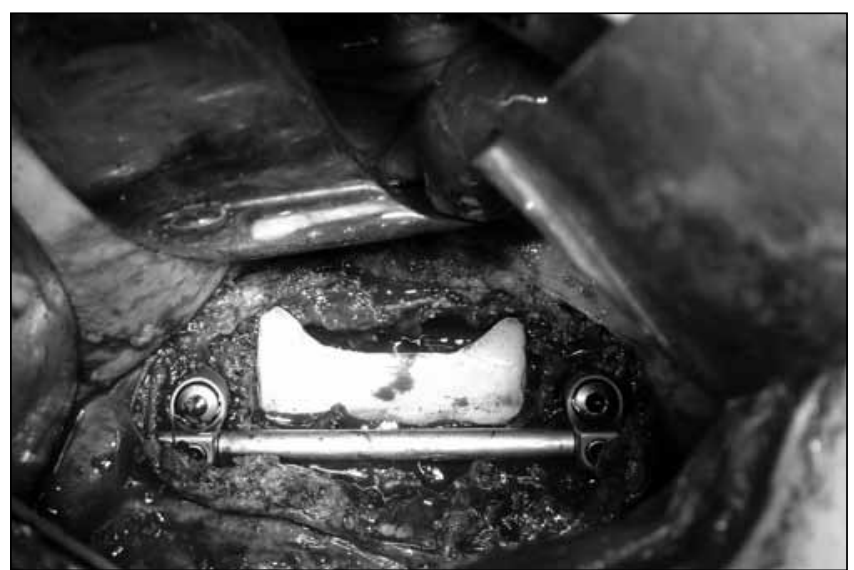

Figure 3: Placement of antibiotic crescent-shaped PMMA strut during the operation.

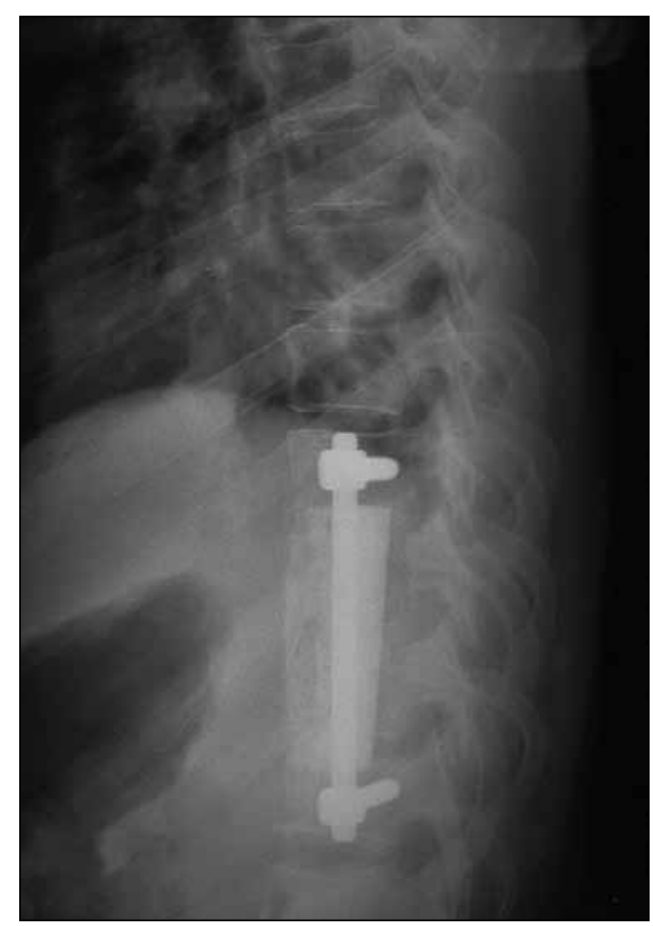

Figure 5: Plain x-ray presented good alignment and satisfactory correction of kyphosis postoperatively (lateral). measured sagittal length of reconstruction area after complete debridement and decompression, then the $20 \mathrm{ml}$ one was put into the $50 \mathrm{ml}$ one with one edge attached together (Figure 6). After mixing with levofloxacin powder and taking on status of wiredrawing, the antibiotic (levofloxacin) bone cement (PMMA) was pressed into the space between the two syringes as much as possible and waited for the hardening (Figure 7). Finally the antibiotic (levofloxacin) crescent-shaped PMMA strut was made successfully by getting rid of the syringe tubes (Figure 8).

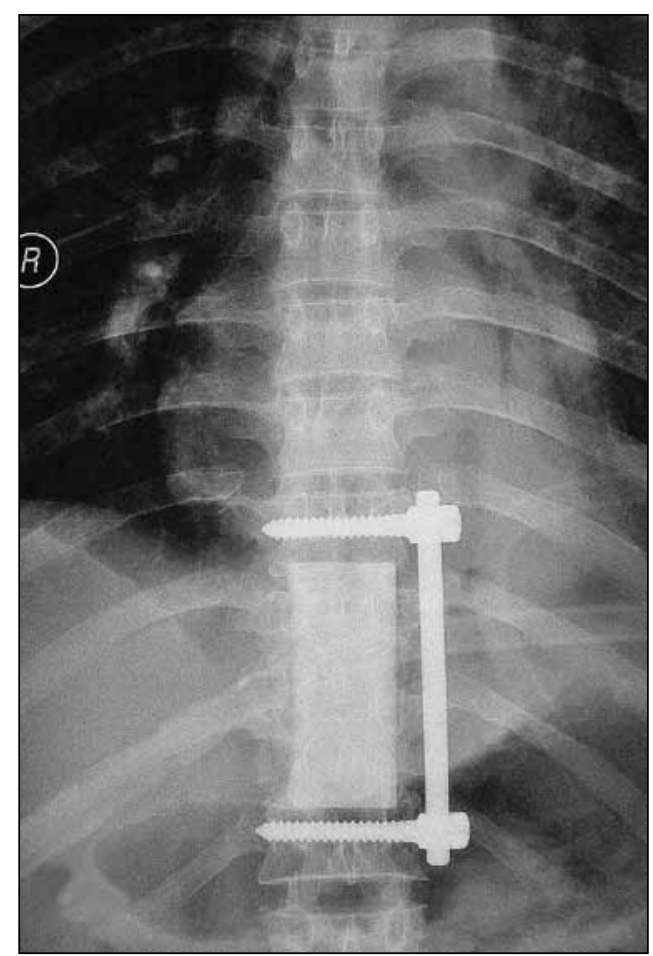

Figure 4: Plain x-ray presented good alignment postoperatively (AP).

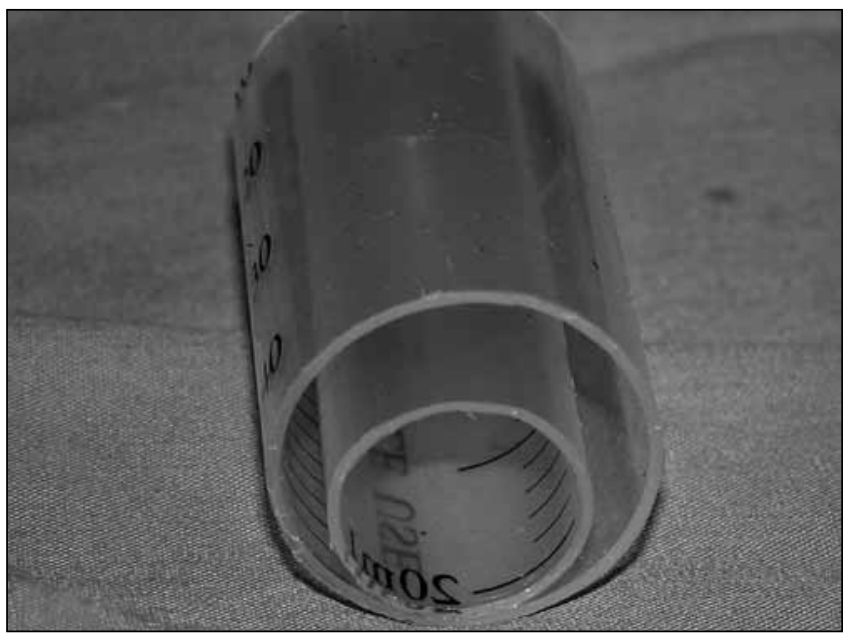

Figure 6: The $20 \mathrm{ml}$ syringe was put into the $50 \mathrm{ml}$ syringe with one edge attached together. 


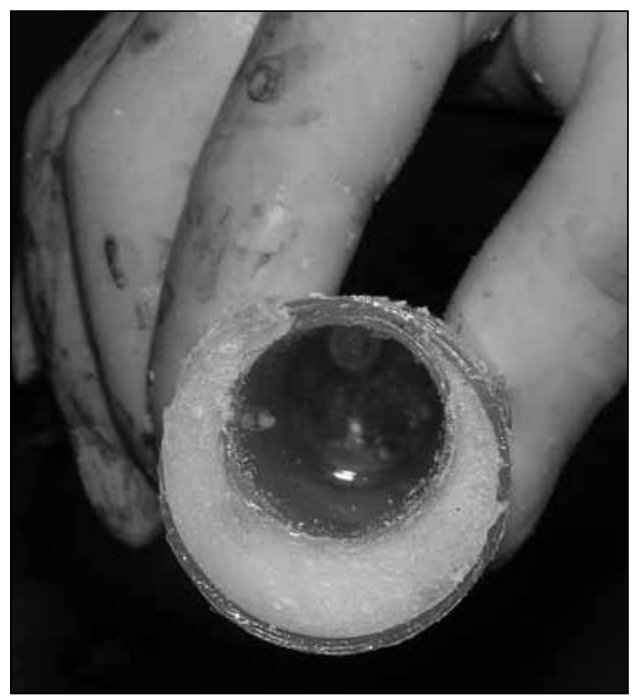

Figure 7: The bone cement (PMMA) was pressed into the space between the two syringes as much as possible and waited for the hardening.

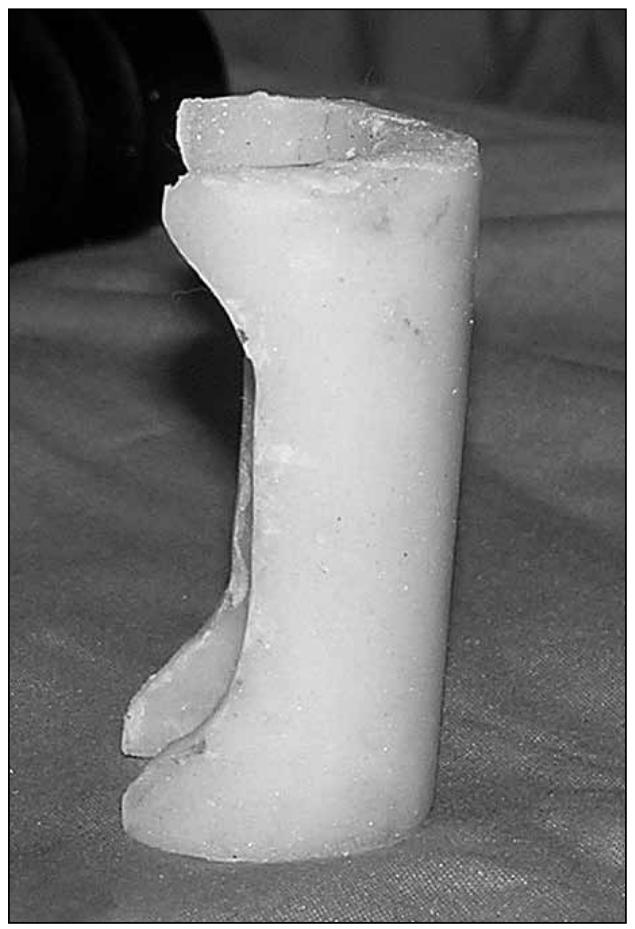

Figure 8: The crescent-shaped PMMA strut was made successfully.

\section{DISCUSSION}

Due to modern diagnostic aids, use of effective antituberculous drugs and advances in surgical treatment, the outcome of spinal tuberculosis has improved significantly. Spinal tuberculosis mainly affects the anterior and middle column of the spine. Despite that the clinical presentation is variable; MRI has led to early diagnosis with a sensitivity of $100 \%$ and specificity of $88 \%(10,27)$ (Figure 2). Biopsy and culture of lesion tissue remains the gold standard in securing a definitive diagnosis. Early initiation of the proper anti-tuberculous medication coupled with resting leads to a favorable outcome in most patients. Surgical debridement and stabilization is indicated in cases of formation of conservative chemotherapy has failed, progressive neurologic deficit because of compression, an epidural abscess or structural destruction resulting in instability (10).

Surgical goals for spinal tuberculosis include eradicating the infection, improve neurological function and maintain spinal stability. The use of anterior approach seems to be more appropriated due to theoretical advantage like more complete debridement and decompression, reliable deformity correction and safer mobilization $(8,11,19)$. The placement of implants in an area of infection, however, is a matter of debate because although implants help provide structural stability, the foreign material in the infected area may influence effect to eradicate the infection $(7,14,22,23,25)$.

Antibiotic-mixed bone cement beads chain are an effective drug delivery system for local antibiotic therapy both in soft-tissue and bone infections $(1,13,15,16,20,24,26,28)$. On the one hand, elution of this mixed type of antibiotic is independent out of types of vascular supply and softtissue compromise. On the other hand, concentration of the antibiotic is significantly higher at the infection site than that found after systemic administration of the same antibiotic $(2,17)$. Because of the very low antibiotic concentration in serum and urine after placement of antibiotic-PMMA beads chain in vivo, toxic side effects are not a concern. However, due to weak support capability, antibiotic-mixed PMMA beads chain are not suitable for application in spinal infective disease when reconstruction required.

PMMA strut has been used clinically in some medical centers mainly for treating cervical diseases $(3,4-6,9,21)$. Chen JF, et al. (3), used an antibiotic- PMMA strut for spinal reconstruction after anterior C5 and C6 corpectomy in one case with cervical pyogenic spondylitis and achieved satisfactory results after the 12-month follow-up. They also reported cases of success on PMMA strut application in anterior spinal reconstruction including PMMA cages after single-level and multilevel cervical discectomy in the treatment of patients with compressive monoradiculopathy and hollow cylindrical PMMA strut for spinal reconstruction after single-level and multilevel cervical corpectomy $(4,5,6)$. Pan $\mathrm{CH}$,et al. (21), described hollow bone cement filled with impacted cacellous bone as a substitute for bone grafts in cervical spine fusion. Good results were observed after mean 19-month follow-up of 21 patients performing the surgery.

Considering that the main nutrition of cancellous bone came from plasma and tissue fluid after separation from blood supply, we designed the PMMA strut as a crescent-shape which can guarantee both the framework capability and enough space left allowing contact of cancellous bone with plasma and tissue fluid (Figures 7, 8). It is also the highlight that, we think, is prior to the cylindrical-shaped PMMA strut $(5,6)$ which absolutely separated cancellous bone from 
plasma and tissue fluid. Meanwhile, because its production was carried out totally during the operation, the length of PMMA strut is completely the same as the sagittal length of the defect area which is prior to preoperative production of PMMA strut according to indirect MRI imaging $(5,6)$.

Radical debridement with removal of all sequestrated bone fragments and all necrotic disc tissue is mandatory before implanting an antibiotic-PMMA strut for spinal reconstruction. Because the posterior elements were intact, additional posterior stabilization leading to $360^{\circ}$ of fusion was not necessary and added risk of tuberculosis transplantation. Primary wound closure is necessary to achieve high local antibiotic concentrations. When adequacy of spinal stability is confirmed, permanent implantation of an antibiotic-PMMA strut is a possible therapeutic modality. In terms of antibiotic type, we choose levofloxacin for its effect on affiliating antituberculosis and better compatibility with PMMA material $(2,12,18)$.

The postoperative deformity correction achieved immediately in our case was satisfactory. (Figures 4, 5) More importantly, deformity correction was maintained and no subsidence and dislodgement of antibiotic crescent-shaped PMMA strut was observed during follow-up. Tuberculous infection was controlled, bony fusion was achieved and substantial pain relief was obtained in our case.

Compared with other options on anterior spinal reconstruction, we think the antibiotic crescent-shaped PMMA strut has its unique advantages: Firstly, it can provide the same framework effect as tricortical autografts without considering morbidity of donor site. Secondly, it has the same property that can be made unlimited size as allografts or titanium mesh cage and universally available. Thirdly, it was made outside the field of operation which minimized the toxicity and the heat injury of PMMA. Fourthly, differentiating from Titanium mesh cages, the anti-tuberculous crescentshaped PMMA strut is composed of not metal but polymer materials which can display sufficient clarity the interface between the vertebra and itself when performing CT scanning (6). Fifthly, it adds local concentration of antibiotics which can attribute to anti-tuberculous chemotherapy and reduce the risk of deep infection by insertion of metal instrumentation postoperatively. Finally, the low cost allows it more appreciating in clinical application.

\section{CONCLUSION}

In our case, an antibiotic crescent-shaped PMMA strut can be used as a carrier for antibiotic drug and an ideal support for anterior spinal reconstruction. Radical debridement followed by anterior reconstruction using antibiotic crescent-shaped PMMA strut offers very satisfactory results in our patient. It provides adequate stability, offers lasting deformity correction, and enables early and safe mobilization. Nevertheless, this study is a case presentation and the absence of a control group limits our ability to ensure similar result might not be obtained with alternative treatments and long-term outcome in this case requires further evaluation.

\section{REFERENCES}

1. AlongeTO, Ogunlade $S O$, Omololu $A B$, Fashina AN, Oluwatosin A: Management of chronic osteomyelitis in a developing country using ceftriaxone-PMMA beads: an initial study. Int J Clin Pract 56(3):181-183, 2002

2. Anguita-Alonso P, Rouse MS, Piper KE, Jacofsky DJ, Osmon $\mathrm{DR}$, Patel R: Comparative study of antimicrobial release kinetics from polymethylmethacrylate. Clin Orthop Relat Res 445:239-244, 2006

3. Chen JF, Lee ST: Antibiotic-polymethylmethacrylate strut: An option for treating cervical pyogenic spondylitis. Case report. J Neurosurg Spine 5(1):90-95, 2006

4. Chen JF, Lee ST, Wu CT: A hollow cylindrical PMMA strut for cervical spine reconstruction after cervical multilevel corpectomy. J Spinal Disord Tech 23(5):321-327, 2010

5. Chen JF, Wu CT, Lee SC, Lee ST: Use of a polymethylmethacrylate cervical cage in the treatment of single-level cervical disc disease. J Neurosurg Spine 3:24-28, 2005

6. Chen JF, Wu CT, Lee SC, Lee ST: Hollow cylindrical polymethylmethacrylate strut for spinal reconstruction after single-level cervical corpectomy. J Neurosurg Spine 5(4):287-293, 2006

7. Choma T, Burrke M, Kim C, Kakarlapudi R: Epidural abscess as a delayed complication of spinal instrumentation in scoliosis surgery: A case of progressive neurologic dysfunction with complete recovery. Spiner (Phila Pa 1976) 33(3):E76-80, 2008

8. Dai LY, Jiang LS, Wang W, Cui YM: Single-stage anterior autogenous bone grafting and instrumentation in the surgical management of spinal tuberculosis. Spine (Phila Pa 1976) 30(20):2342-2349, 2005

9. Hamburger C, Festenberg FV, Uhl E: Ventral discectomy with PMMA interbody fusion for cervical disc disease: Long-term results in 249 patients. Spine 26:249-255, 2001

10. Jain AK: Tuberculosis of the spine: $A$ fresh look at an old disease. J Bone Joint Surg Br J 92(7):905-913, 2010

11. Jin D, Qu D, Chen J, Zhang H: One-stage anterior interbody autografting and instrumentation in primary surgical management of thoracolumbar spinal tuberculosis. Eur Spine J 13(2):114-121, 2004

12. Johnson JL, Hadad DJ, Boom WH, Daley CL, Peloquin CA, Eisenach KD: Early and extended early bactericidal activity of levofloxacin, gatifloxacin and moxifloxacin in pulmonary tuberculosis. Int J Tuberc Lung Dis 10(6):605-612, 2006

13. Joseph TN, Chen AL, Di Cesare PE: Use of antibioticimpregnated cement in total joint arthroplasty. J Am Acad Orthop Surg 11(1):38-47, 2003

14. Kim JI, Suh KT, Kim SJ, Lee JS: Implant removal for the management of infection after instrumented spinal fusion. J Spinal Disord Tech 23(4):258-265, 2010

15. Klemm K: The use of antibiotic-containing bead chains in the treatment of chronic bone infections. Clin Microbiol Infect 7(1):28-31, 2001

16. Krause FG, deVries G, Meakin C, Kalla TP, Younger AS: Outcome of transmetatarsal amputations in diabetics using antibiotic beads. Foot Ankle Int 30(6):486-493, 2009 
17. Lee $\mathrm{CG}$, Fu YC, Wang $\mathrm{CH}$ : Simulation of gentamicin delivery for the local treatment of osteomyelitis. Biotechnol Bioeng 91(5):622-635, 2005

18. Lin SY, Desmond E, Bonato D, Gross W, Siddiqi S: Multicenter evaluation of Bactec MGIT 960 system for second-line drug susceptibility testing of Mycobacterium tuberculosis complex. J Clin Microbiol 47(11):3630-3634, 2009

19. Mihir B, Vinord L, Umesh M, Chaudhary K: Anterior instrumentation of the cervicothoracic vertebrae: Approach based on clinical and radiologic criteria. Spine (Phila Pa 1976) 31(9):E244-249, 2006

20. Mohanty SP, Kumar MN, Murthy NS: Use of antibiotic-loaded polymethyl methacrylate beads in the management of musculoskeletal sepsis--a retrospective study. J Orthop Surg (Hong Kong) 11(1):73-79, 2003

21. Pan HC, Wang YC, Lee CH, Yang DY: Hollow bone cement filled with impacted cancellous bone as a substitute for bone grafts in cervical spine fusion. J Clin Neurosci 14(2):143-147, 2007

22. Rihn JA, Lee JrY, Ward WT: Infection after the surgical treatment of adolescent idiopathic scoliosis: Evaluation of the diagnosis, treatment, and impact on clinical outcomes. Spine (Phila Pa 1976) 33(3):289-294, 2008
23. Soultanis K, Mantelos G, Pagiatakis A, Soucacos PN: Late infection in patients with scoliosis treated with spinal instrumentation. Clin Orthop Relat Res 411:116-123, 2003

24. Stone PA, Armstrong PA, Bandyk DF, Brumberg RS, Flaherty SK, Back MR, Johnson BL, Shames ML: Use of antibioticloaded polymethylmethacrylate beads for the treatment of extra-cavitary prosthetic vascular graft infections. J Vasc Surg 44(4):757-761, 2006

25. Talu U, Gogus A, Ozturk C, Hamzaoglu A, Domanic U: The role of posterior instrumentation and fusion after anterior radical debridement and fusion in the surgical treatment of spinal tuberculosis: Experience of 127 cases. J Spinal Disord Tech 19(8):554-559, 2006

26. Taggart T, Kerry RM, Norman P, Stockley I: The use of vancomycin-impregnated cement beads in the management of infection of prosthetic joints. J Bone Joint Surg $\mathrm{Br}$ 84(1):70-72, 2002

27. Tuli SM: Tuberculosis of the spine: A historical review. Clin Orthop Relat Res 460: 29-38, 2007

28. Wang J, Calhoun JH, Mader JT:The application of bioimplants in the management of chronic osteomyelitis. Orthopedics 25(11):1247-1252, 2002 